\title{
Hubungan Kadar Albumin Serum dengan Morbiditas dan Mortalitas Maternal Pasien Preeklampsia Berat dan Eklampsia di RSUP Dr. M. Djamil Padang
}

\author{
Yunike Veronika ${ }^{1}$, Joserizal Serudji ${ }^{2}$, Susila Sastri ${ }^{3}$
}

\begin{abstract}
Abstrak
Preeklampsia dan eklampsia merupakan penyebab utama morbiditas dan mortalitas ibu dan bayi di dunia, dimana terjadi penurunan albumin serum (hipoalbuminemia) sehingga tekanan hipovolemik intravaskular berkurang. Tujuan penelitian ini adalah untuk mengetahui hubungan kadar albumin serum dengan morbiditas dan mortalitas maternal pasien preeklampsia berat dan eklampsia. Penelitian ini bersifat analitik observasional retrospektif dilakukan dengan desain cross sectional study. Populasi penelitian adalah seluruh data rekam medis pasien preeklampsia berat dan eklampsia di RSUP Dr. M. Djamil Padang periode Januari 2012 - Desember 2012. Sampel ditetapkan dengan teknik total sampling sehingga didapatkan sampel sebanyak 133 kasus. Pengolahan data dilakukan secara komputerisasi dan analisis dengan uji chi-square. Hasil penelitian menunjukkan angka kejadian morbiditas maternal adalah 33,8\%, mortalitas maternal 3,8\% dan 3,8\% pasien dengan hipoalbuminemia. Dari hasil analisis, tidak terdapat hubungan yang bermakna antara kadar albumin serum dengan morbiditas dan mortalitas maternal pasien preeklampsia berat dan eklampsia, dimana nilai $p=1$ untuk hubungan kadar albumin serum dengan morbiditas maternal dan $p=0,177$ untuk hubungan kadar albumin serum dengan mortalitas maternal pasien preeklampsia berat dan eklampsia $(p>0,05)$.
\end{abstract}

Kata kunci: preeklampsia berat, eklampsia, albumin serum

\begin{abstract}
Preeclampsia and eclampsia are major causes of maternal and fetal morbidity and mortality in the world, in which serum albumin decreases (hypoalbuminemia) so hypovolemic intravascular pressure will be reduced. The objective of this study was to determine the relation between serum albumin levels and maternal morbidity and mortality of severe preeclampsia and eclampsia patients. A retrospective observational analytical research was conducted with a cross sectional study design. The study population was the entire medical records of severe preeclampsia and eclampsia patients in RSUP Dr. M. Djamil Padang, period January 2012 - December 2012. The sample was determined by total sampling technique which obtained a sample of 133 cases. Data processing was computerized and analyzed by chi-square test. The incidence of maternal morbidity was 33.8\%, maternal mortality was $3.8 \%$, and $3.8 \%$ patients were with hypoalbuminemia. The analysis result obtained there was no significant correlation between serum albumin levels and maternal morbidity and mortality of severe preeclampsia and eclampsia patients, in which $p=1$ for serum albumin levels correlation with maternal morbidity and $p=0.177$ for serum albumin levels correlation with maternal mortality of severe preeclampsia and eclampsia patients $(p>0.05)$.
\end{abstract}

Keywords: severe preeclampsia, eclampsia, serum albumin

Affiliasi penulis: 1.Pendidikan Dokter FK UNAND (Fakultas Kedokteran Universitas Andalas Padang), 2. Bagian Obstetri Ginekologi FK UNAND/ RS Dr. M. Djamil Padang, 3. Bagian Biokimia FK UNAND
Korespondensi: Yunike Veronika, E-mail:

yunikeveronika@ymail.com, Telp: 081276610667 


\section{PENDAHULUAN}

Angka Kematian Ibu (AKI) menggambarkan status gizi, kondisi kesehatan lingkungan, dan tingkat pelayanan kesehatan terhadap ibu hamil, melahirkan, dan nifas. ${ }^{1}$ World Health Organization (WHO) memperkirakan kematian ibu di seluruh dunia sebesar 500.000 jiwa pertahun yang disebabkan karena perdarahan (25\%), penyebab tidak langsung (20\%), infeksi (15\%), aborsi yang tidak aman (13\%), preeklampsia dan eklampsia (12\%), persalinan kurang baik $(8 \%)$, dan penyebab langsung lainnya $(8 \%){ }^{2}$

Preeklampsia dan eklampsia merupakan penyebab utama morbiditas dan mortalitas ibu dan bayi di dunia khususnya di negara berkembang dengan angka kejadian berkisar antara 0,3\% sampai 0,7\%, sedangkan di negara-negara maju angka kejadian lebih kecil, yaitu $0,05 \%$ sampai $0,1 \% .^{3} \mathrm{Di}$ Asia, preeklampsia berat yang merupakan salah satu gangguan hipertensi pada kehamilan menduduki peringkat keenam dengan persentase sekitar $9,1 \%{ }^{4}$

Di Indonesia, preeklampsia berat dan eklampsia merupakan penyebab kematian ibu berkisar antara $1,5 \%$ sampai $25 \%$, sedangkan kematian bayi antara $45 \%$ sampai $50 \%{ }^{3}$ Preeklampsia berat yang mendapatkan penanganan tidak adekuat sehingga berlanjut menjadi eklampsia menduduki peringkat kedua sebagai penyebab kematian ibu dengan persentase $24 \%$ di Indonesia, setelah haemorragic post partum sebesar $28 \% .^{5}$ Angka kejadian preeklampsia berat di RSUP Dr. M. Djamil Padang selama tahun 2006 adalah sekitar 7,3\% yaitu sebanyak 85 kasus dari 1324 persalinan.

Salah satu penyebab utama mortalitas maternal pada penderita preeklampsia dan eklampsia adalah edema paru. Hal ini biasanya disebabkan oleh dekompensasio kordis kiri, kelebihan cairan ekstravaskular, penurunan tekanan koloid plasma akibat proteinuria, penggunaan kristaloid untuk mengganti kehilangan darah serta penurunan sintesis albumin di hepar. ${ }^{6}$

Aliran darah ginjal dan kecepatan filtrasi glomerulus selama kehamilan meningkat bila dibandingkan dengan keadaan tidak hamil. Dengan timbulnya hipertensi dalam kehamilan, perfusi darah pada ginjal dan kecepatan filtrasi glomerulus menurun secara bervariasi, seperti halnya glomerulopati, dimana terdapat peningkatan permeabilitas terhadap protein plasma misalnya albumin. ${ }^{7}$

Pada preeklampsia dan eklampsia, penurunan laju filtrasi glomerulus pada ginjal terjadi akibat spasme arteri renalis yang menyebabkan penyerapan terhadap protein berkurang sehingga terjadi proteinuria, selanjutnya terjadi penurunan albumin serum (hipoalbuminemia) sehingga tekanan hipovolemik intravaskular akan berkurang. ${ }^{8}$

Albumin merupakan protein yang paling banyak terdapat dalam serum. Disamping berperan dalam tekanan osmotik koloid, albumin juga bekerja sebagai molekul pengangkut untuk bilirubin, asam lemak, dan obat-obatan. $^{7}$

Kadar albumin serum yang rendah (hipoalbuminemia) berhubungan dengan sirkulasi fetoplasenta yang tidak memadai, sebagai akibat dari hipoperfusi multiorgan dan kerusakan endotel menyeluruh. Hipoksia plasenta merangsang pelepasan zat vasoaktif dalam darah yang memiliki efek pada jantung. Peningkatan tekanan perfusi menyebabkan perpindahan cairan ke dalam cairan interstisial sehingga terjadi edema dan hipovolemia. Penurunan volume intravaskular lebih lanjut mengurangi perfusi organ, menyebabkan pelepasan katekolamin dengan penurunan perfusi secara bersamaan pada ginjal dan hati. Hipoperfusi hati menentukan penurunan produksi albumin yang mengakibatkan hipoalbuminemia dan penurunan tekanan onkotik yang selanjutnya menyebabkan perpindahan cairan dan edema yang memburuk. ${ }^{9}$

Hipoalbuminemia adalah penanda keparahan klinis pada berbagai kondisi, termasuk preeklampsia dan menunjukkan keterlibatan ginjal yang penting. Hipoalbuminemia pada preeklampsia dapat menyebabkan kerusakan ginjal lebih daripada penyakit hipertensi saja. Ini menunjukkan bahwa hipoalbuminemia merupakan tanda prognostik negatif dan penanda untuk disfungsi sistemik yang parah. ${ }^{9}$

Berdasarkan permasalahan yang telah diuraikan di atas, maka perlu dilakukan penelitian mengenai hubungan kadar albumin serum dengan morbiditas dan mortalitas maternal pasien preeklampsia berat dan eklampsia di RSUP Dr. M. Djamil Padang. 


\section{METODE}

Penelitian ini bersifat analitik observasional retrospektif dengan desain cross sectional study. Penelitian dilakukan di sub bagian Rekam Medis (Medical Record) RSUP Dr. M. Djamil Padang yang dilakukan periode Februari - April 2013. Populasi penelitian ini adalah seluruh data rekam medis pasien yang didiagnosis sebagai kasus preeklampsia berat dan eklampsia di RSUP Dr. M. Djamil Padang selama periode Januari 2012 - Desember 2012. Data Sampel diambil dengan menggunakan teknik total sampling sehingga didapatkan sampel sebanyak 133. Data sampel yang diambil adalah seluruh populasi yang memenuhi kriteria inklusi dan eksklusi. Kriteria inklusi adalah pasien dengan usia kehamilan di atas 20 minggu yang telah didiagnosis preeklampsia berat dan eklampsia di RSUP Dr. M. Djamil Padang. Kriteria eksklusi adalah pasien dengan riwayat penyakit kronis yang dapat menurunkan kadar albumin serum dan pasien dengan data rekam medis yang tidak lengkap. Pengolahan data dilakukan secara komputerisasi dan dianalisis dengan uji chi-square.

\section{HASIL}

Tabel 1. Distribusi frekuensi subjek penelitian menurut karakteristik usia ibu (tahun)

\begin{tabular}{cccccc}
\hline $\begin{array}{c}\text { Kadar Albumin } \\
\text { Serum }\end{array}$ & $\mathbf{f}$ & Rerata & SD & Min & Maks \\
\hline Normal & 128 & 28,91 & 6,77 & 15 & 43 \\
Hipoalbuminemia & 5 & 30,80 & 4,97 & 24 & 37 \\
\hline
\end{tabular}

Tabel 1 menunjukkan rerata usia ibu pada kelompok kadar albumin serum normal adalah 28,91 \pm 6,77 tahun dengan usia ibu terendah 15 tahun dan tertinggi 43 tahun. Pada kelompok hipoalbuminemia, rerata usia ibu adalah 30,80 \pm 4,97 tahun dengan usia ibu terendah 24 tahun dan tertinggi 37 tahun. Usia ibu antara pasien dengan kadar albumin serum normal dan hipoalbuminemia didapatkan angka distribusi yang hampir sama.

Tabel 2. Distribusi frekuensi morbiditas dan mortalitas maternal pasien preeklampsia berat dan eklampsia

\begin{tabular}{cccc}
\hline & & \multicolumn{2}{c}{$\begin{array}{c}\text { Preeklampsia Berat } \\
\text { dan Eklampsia }\end{array}$} \\
\cline { 2 - 4 } & & $\mathbf{n}$ & $\%$ \\
\hline \multirow{3}{*}{$\begin{array}{c}\text { Morbiditas } \\
\text { Maternal }\end{array}$} & Ada & 45 & 33,8 \\
& Tidak ada & 88 & 66,2 \\
\cline { 2 - 4 } & Total & $\mathbf{1 3 3}$ & $\mathbf{1 0 0}$ \\
\hline \multirow{3}{*}{ Mortalitas } & Ya & 5 & 3,8 \\
& Tidak & 128 & 96,2 \\
\cline { 2 - 4 } & Total & 133 & 100 \\
\hline
\end{tabular}

Tabel 2 menunjukkan pasien preeklampsia berat dan eklampsia yang mengalami morbiditas maternal adalah sebanyak 45 orang $(33,8 \%)$ dan 88 orang $(66,2 \%)$ tidak mengalami morbiditas. Mortalitas maternal terjadi pada 5 orang (3,8\%) pasien dan 128 orang $(96,2 \%)$ tidak mengalami mortalitas.

Tabel 3. Distribusi frekuensi kadar albumin serum pada pasien preeklampsia berat dan eklampsia

\begin{tabular}{cccc} 
& & \multicolumn{2}{c}{$\begin{array}{c}\text { Preeklampsia Berat } \\
\text { dan Eklampsia }\end{array}$} \\
\cline { 3 - 4 } & & $\mathbf{n}$ & $\%$ \\
\hline \multirow{2}{*}{$\begin{array}{c}\text { Kadar } \\
\text { Serumin }\end{array}$} & Normal & 128 & 96,2 \\
\cline { 2 - 4 } & Hipoalbuminemia & 5 & 3,8 \\
\hline
\end{tabular}

Tabel 3 menunjukkan pasien preeklampsia berat dan eklampsia yang mengalami hipoalbuminemia sebanyak 5 orang (3,8\%). Sedangkan 128 orang (96,2\%) pasien memiliki kadar albumin serum dalam batas normal. 
Tabel 4. Hubungan kadar albumin serum dengan morbiditas maternal

\begin{tabular}{ccccccccc}
\hline \multirow{2}{*}{$\begin{array}{c}\text { Kadar } \\
\text { Albumin }\end{array}$} & \multicolumn{4}{c}{ Morbiditas Maternal } & \multicolumn{3}{c}{ Total } & \\
\cline { 2 - 5 } & \multicolumn{2}{c}{ Ada } & \multicolumn{3}{c}{ Tidak ada } & & & $\mathbf{p}$ \\
\cline { 2 - 6 } & $\mathbf{n}$ & $\%$ & $\mathbf{n}$ & $\%$ & $\mathbf{n}$ & $\%$ & \\
\hline Normal & 43 & 33,59 & 85 & 66,41 & 128 & 100 & \\
Hipo & 2 & 40 & 3 & 60 & 5 & 100 & \\
albuminemia & & & & & & & \\
\hline
\end{tabular}

Tabel 4 menunjukkan proporsi morbiditas maternal lebih banyak terjadi pada subjek penelitian dengan kadar albumin normal bila dibandingkan dengan subjek penelitian dengan hipoalbuminemia. Pada hasil pengolahan data di atas dapat dilihat bahwa didapatkan nilai $p=1$ (dimana nilai $p$ yang dianggap bermakna adalah $<0,05$ ), yang artinya tidak ada hubungan secara signifikan antara kadar albumin serum dengan morbiditas maternal. Maknanya, morbiditas maternal dapat terjadi pada berbagai kadar albumin serum.

Tabel 5. Hubungan antara kadar albumin serum dengan mortalitas maternal

\begin{tabular}{|c|c|c|c|c|c|c|c|}
\hline \multirow{3}{*}{$\begin{array}{c}\text { Kadar Albumin } \\
\text { Serum }\end{array}$} & \multicolumn{4}{|c|}{ Mortalitas Maternal } & \multirow{2}{*}{\multicolumn{2}{|c|}{ Total }} & \multirow{3}{*}{$\mathbf{p}$} \\
\hline & \multicolumn{2}{|r|}{ Ya } & \multicolumn{2}{|r|}{ Tidak } & & & \\
\hline & $\mathbf{n}$ & $\%$ & $\mathbf{n}$ & $\%$ & $\mathbf{n}$ & $\%$ & \\
\hline \multirow[t]{2}{*}{ Normal } & 4 & 3,12 & 124 & 96,88 & 128 & 100 & \multirow{3}{*}{0,177} \\
\hline & & & & & & & \\
\hline Hipoalbuminemia & 1 & 20 & 4 & 80 & 5 & 100 & \\
\hline
\end{tabular}

Tabel 5 menunjukkan proporsi mortalitas maternal lebih banyak terjadi pada subjek penelitian dengan kadar albumin normal bila dibandingkan dengan subjek penelitian dengan hipoalbuminemia. Pada hasil pengolahan data di atas dapat dilihat bahwa didapatkan nilai $p=0,177$, yang artinya tidak ada hubungan secara signifikan antara kadar albumin serum dengan mortalitas maternal. Maknanya, mortalitas maternal dapat terjadi pada berbagai kadar albumin serum.

\section{PEMBAHASAN}

Analisis data penelitian ini didapatkan hubungan yang tidak bermakna antara kadar albumin serum dengan morbiditas dan mortalitas maternal pasien preeklampsia berat dan eklampsia, dimana didapatkan nilai $p=1$ untuk morbiditas maternal dan $p=0,177$ untuk mortalitas maternal ( $p>0,05)$. Maknanya, morbiditas dan mortalitas maternal dapat terjadi pada pasien dengan kadar albumin serum normal maupun hipoalbuminemia. Hasil ini sejalan dengan penelitian yang dilakukan oleh Sari pada tahun 2009 di RSUD Dr. Moewardi Surakarta didapatkan bahwa tidak ada pengaruh kadar albumin serum $<3,4 \mathrm{gr} / \mathrm{dL}$ terhadap morbiditas dan mortalitas maternal pada pasien preeklampsia/eklampsia dengan nilai $p=0,253$ dan $p=0,702(p>0,05){ }^{10}$

Secara teoritis, hipoalbuminemia adalah penanda keparahan klinis pada berbagai kondisi, termasuk preeklampsia dan menunjukkan keterlibatan ginjal yang penting. Hal ini berhubungan dengan sirkulasi feto-plasenta yang tidak memadai, sebagai akibat dari hipoperfusi multiorgan dan kerusakan endotel secara menyeluruh. ${ }^{9}$ Dalam suatu tinjauan terbaru, konsentrasi albumin serum juga merupakan prediktor independen kematian dalam berbagai kondisi klinis. $^{11}$

Perbedaan hasil penelitian ini dengan studi yang telah ada mungkin disebabkan karena berbagai keterbatasan yang terjadi selama penelitian. Pada penelitian ini, tidak semua populasi dapat disertakan karena ketidaklengkapan data pada status pasien di bagian Rekam Medis RSUP Dr. M. Djamil Padang, sehingga jumlah data yang harus dieksklusi jauh lebih banyak dari yang diperkirakan.

Penelitian ini tidak memperhitungkan faktorfaktor lain yang mempengaruhi kadar albumin serum sehingga juga dapat mempengaruhi angka kejadian morbiditas dan mortalitas maternal. Satu-satunya terapi definitif untuk preeklampsia adalah persalinan sehingga proses patofisiologi preeklampsia berat berhenti. Tujuan lain dari terapi yaitu mencegah kejang dengan antikonvulsan dan memulihkan kondisi kesehatan ibu. ${ }^{12,13}$ Pada pasien dengan kehamilan aterm, terminasi kehamilan dapat segera dilakukan. Preeklampsia berat yang ditangani dengan cepat dapat mencegah terjadinya morbiditas dan mortalitas maternal pada pasien. Namun, pada penelitian ini didapatkan beberapa pasien dengan usia kehamilan preterm sehingga persalinan tidak dapat segera 
dilakukan. Pasien akan terus dipantau kondisinya dan diikuti dengan pertimbangan telah tercapainya kondisi yang optimal untuk persalinan dilihat dari sisi kematangan paru janin. Hal ini menyebabkan patofisiologi preeklampsia berat terus berlanjut sehingga memungkinkan terjadinya morbiditas dan mortalitas maternal selama perawatan meskipun kadar albumin serum pasien pada awalnya normal.

Penelitian ini hanya menilai kadar albumin serum pada saat pasien pertama kali didiagnosis preeklampsia berat dan eklampsia sesuai dengan metode penelitian yang dipakai yaitu cross sectional study tanpa adanya follow up pada pemeriksaan kadar albumin serum berikutnya. Kadar albumin serum yang rendah mungkin dapat mengalami peningkatan selama perawatan setelah mendapat penatalaksanaan koreksi albumin sehingga dapat mengurangi risiko morbiditas dan mortalitas. Faktor gizi pasien juga dapat mempengaruhi kadar albumin serum.

Kriteria penegakan diagnosis preeklampsia berat adalah apabila ditemukan satu atau lebih gejala dari preeklampsia berat, terutama tekanan darah sistolik $\geq 160 \mathrm{mmHg}$ dan diastolik $\geq 110 \mathrm{mmHg}^{13}$ Namun terkadang kondisi pasien sering ditemukan dengan proteinuria $<4+$ sehingga kadar albumin serum pasien masih dalam batas normal. Kadar albumin serum yang normal akan mengurangi risiko terjadinya morbiditas dan mortalitas maternal pada pasien dengan preeklampsia berat.

Penelitian ini memiliki keterbatasan, namun diharapkan tetap dapat memberikan manfaat dalam upaya pendeteksian dan penatalaksanaan dini terhadap kadar albumin serum yang rendah pada pasien preeklampsia berat dan eklampsia sehingga risiko terjadinya morbiditas dan mortalitas maternal dapat diturunkan. Selain itu, penelitian ini diharapkan dapat memberikan ide dan dapat menjadi pembanding bagi penelitian selanjutnya.

\section{UCAPAN TERIMA KASIH}

Ucapan terima kasih kepada Dr. dr. H. Joserizal Serudji, Sp.OG(K) dan dr. Susila Sastri, M.Biomed, yang telah banyak memberikan bimbingan, bantuan dan motivasi dalam penelitian ini.

\section{DAFTAR PUSTAKA}

1. Langelo W, Arsin AA, Russeng S. Faktor risiko kejadian preeklampsia di RSKD ibu dan anak Siti Fatimah Makassar tahun 2011-2012. Makassar: Fakultas Kesehatan Masyarakat Universitas Hasanuddin; 2012.

2. World Health Organization. Beyond the numbers: reviewing maternal deaths and complications to make pregnancy safer. Geneva: World Health Organization; 2004.

3. Djannah SN, Arianti IS. Gambaran epidemiologi kejadian preeklampsia/eklampsia di RSU PKU Muhammadiyah Yogyakarta Tahun 2007-2009. Buletin Penelitian Sistem Kesehatan. 2010;13(4): 378-85.

4. World Health Organization. Maternal and perinatal health. Geneva: World Health Organization; 2006.

5. Departemen Kesehatan Republik Indonesia. Profil kesehatan Indonesia, Jakarta: Departemen Kesehatan Republik Indonesia; 2007.

6. Maria A. Faktor-faktor risiko preeklampsia berat di RS. Dr. M. Djamil Padang Tahun 2006 (skripsi). Padang: Fakultas Kedokteran Universitas Andalas; 2007.

7. Lintang LS. Gambaran fraksi protein darah pada preeklampsia dan hamil normotensif. Medan: Bagian Obstetri dan Ginekologi Fakultas Kedokteran Sumatera Utara RSUP H. Adam Malik/RSUD Dr. Pirngadi Medan; 2003.

8. Dewi AK, Istanti E, Yuliani GN, Damayanti IP. Laserasi jalan lahir post vakum ekstraksi atas indikasi PEB, gemelli (preskep-preskep), KPD 10 jam potential infected pada primigravida hamil preterm dengan hipoalbuminemia. Surakarta: Kepaniteraan Klinik IImu Kebidanan dan Kandungan Fakultas Kedokteran UNS/RSUD Dr. Moewardi Surakarta; 2007.

9. Giovanni L, Maria LG, Mauro R, Carlotta M, Federica $R$, Fabrizio $P$, et al. Thrombophilia and damage of kidney during pregnancy. Journal of Prenatal Medicine. 2011;5(4):78-82.

10. Sari NK. Pengaruh kadar albumin serum terhadap 
morbiditas dan mortalitas maternal pada pasien preeklampsia/eklampsia di RSUD Dr. Moewardi Surakarta (skripsi). Surakarta: Fakultas Kedokteran Universitas Sebelas Maret; 2009.

11. Yap FHY, Joynt GM, Buckley TA, Wong ELY. Association of serum albumin concentration and mortality risk in critically ill patients. Anaesthesia and Intensive Care. 2002;30:202-7.
12. Bourgeois FJ, Gehric PA, Veljovich DS. Obstetric and gynecology recall. Edisi ke-2. Philadelphia: Williams \& Wilkins; 2005.

13. Angsar MD. Hipertensi dalam kehamilan. Dalam: Saifuddin AB, Rachimhadhi T, Wiknjosastro GH, editor (penyunting). Ilmu Kebidanan Sarwono Prawirohardjo. Jakarta: PT. Bina Pustaka Sarwono Prawirohardjo; 2010. hlm. 530-61. 